\title{
Suitability of vaccinia virus and bovine viral diarrhea virus (BVDV) for determining activities of three commonly-used alcohol-based hand rubs against enveloped viruses
}

\author{
Günter Kampf*1,2, Jochen Steinmann ${ }^{3}$ and Holger Rabenau ${ }^{4}$
}

\author{
Address: ${ }^{1}$ Bode Chemie GmbH \& Co. KG, Scientific Affairs, Melanchthonstr. 27, 22525 Hamburg, Germany, ${ }^{2}$ Institut für Hygiene und \\ Umweltmedizin, Ernst-Moritz-Arndt Universität Greifswald, Walther-Rathenau-Str. 49a, 17489 Greifswald, Germany, ${ }^{3} \mathrm{MikroLab}$ GmbH, \\ Norderoog 2, 28259 Bremen, Germany and ${ }^{4}$ Institut für Medizinische Virologie, Klinikum der Johann Wolfgang Goethe-Universität Frankfurt, \\ Paul-Ehrlich-Str. 40, 60596 Frankfurt, Germany \\ Email: Günter Kampf* - guenter.kampf@bode-chemie.de; Jochen Steinmann - Mikrolab.GmbH@t-online.de; \\ Holger Rabenau - rabenau@em.uni-frankfurt.de \\ * Corresponding author
}

Published: 9 February 2007

BMC Infectious Diseases 2007, 7:5 doi:10.1 186/147/-2334-7-5
Received: 16 August 2006

Accepted: 9 February 2007

This article is available from: http://www.biomedcentral.com/I47/-2334/7/5

(C) 2007 Kampf et al; licensee BioMed Central Ltd.

This is an Open Access article distributed under the terms of the Creative Commons Attribution License (http://creativecommons.org/licenses/by/2.0), which permits unrestricted use, distribution, and reproduction in any medium, provided the original work is properly cited.

\begin{abstract}
Background: A procedure for including activity against enveloped viruses in the postcontamination treatment of hands has been recommended, but so far no European standard is available to implement it. In 2004, the German Robert Koch-Institute (RKI) and the German Association for the Control of Virus Disease (DVV) suggested that vaccinia virus and bovine viral diarrhea virus (BVDV) should be used as test viruses in a quantitative suspension test to determine the activity of a disinfectant against all enveloped viruses.
\end{abstract}

Methods: We have studied the activities of three commonly-used alcohol-based hand rubs (hand rub $\mathrm{A}$, based on $45 \%$ propan-2-ol, $30 \%$ propan-I-ol and $0.2 \%$ mecetronium etilsulfate; hand rub $\mathrm{B}$, based on $80 \%$ ethanol; hand rub C, based on $95 \%$ ethanol) against vaccinia virus and BVDV, and in addition against four other clinically relevant enveloped viruses: herpes simplex virus (HSV) types $I$ and 2 , and human and avian influenza $A$ virus. The hand rubs were challenged with different organic loads at exposure time of 15,30 and $60 \mathrm{~s}$. According to the guidelines of both BGA/RKI and DVV, and EN 14476:2005, the reduction of infectivity of each test virus was measured on appropriate cell lines using a quantitative suspension test.

Results: All three alcohol-based hand rubs reduced the infectivity of vaccinia virus and BVDV by $\geq 4 \log _{10^{-}}$-steps within $15 \mathrm{~s}$, irrespective of the type of organic load. Similar reductions of infectivity were seen against the other four enveloped viruses within $15 \mathrm{~s}$ in the presence of different types of organic load.

Conclusion: Commonly used alcohol-based hand rubs with a total alcohol concentration $\geq 75 \%$ can be assumed to be active against clinically relevant enveloped viruses if they effectively reduce the infectivities of vaccinia virus and BVDV in a quantitative suspension test. 


\section{Background}

During the past few years, many healthcare workers have changed from antimicrobial liquid soaps to alcohol-based hand rubs for the post-contamination treatment of hands, as suggested by the CDC guideline for hand hygiene [1]. The two main reasons are broader and faster efficacy, which is beneficial in preventing cross-transmission of nosocomial pathogens $[2,3]$, and superior dermal tolerance, which is beneficial for compliance with hand hygiene regulations $[3,4]$. Recently it has been suggested that a preparation for routine hand hygiene should be active at least against bacteria, yeasts and enveloped viruses [3]. This minimum spectrum of activity is based on data on the contamination of healthcare workers' hands, on the transmissibility of nosocomial pathogens, and on outbreaks of nosocomial infections caused by contaminated hands of healthcare workers [3]. Quantitative suspension tests are used to determine the spectrum of activity [5]. Recommendations for use in the hospital are usually derived from efficacy tests under practical conditions [5]. Bactericidal activity can be determined according to prEN 13727 (formerly prEN 12054) [6]. It has been shown using a propanol-based hand rub that the four test bacteria of this test norm cover the whole spectrum of nosocomial bacterial strains and clinical isolates including emerging pathogens [7]. For fungicidal activity, only a basic test (EN 1275) is available [8]. One of the two test fungi for EN 1275 is Candida albicans, which may serve as the clinically relevant test strain for determining activity against yeasts. To determine virucidal activity, EN 14476:2005 should be used [9]. However, this European norm is only designed for determining "complete virucidal activity", which for hand disinfection includes only two non-enveloped viruses: adenovirus type 5 and poliovirus type 1. No European norm is available for determining activity specific against enveloped viruses, although a national test method has recently been published by the German Association for the Control of Virus Disease (DVV) and the Robert Koch-Institute (RKI) [10]. Such a test norm at the European level would certainly be desirable. The RKI has recently used the phrase "limited virucidal activity" ("active against enveloped viruses such as HIV, HBV, and HCV") to describe a preparation that has proven active against two representative enveloped viruses, vaccinia virus and bovine viral diarrhea virus (BVDV) [11]. BVDV serves as a model for Hepatitis C Virus (HCV) because this pestivirus also belongs to the family Flaviviridae and has some properties similar to HCV [12-14].

To date, however, there is no evidence to show that the two chosen test viruses cover other clinically relevant enveloped viruses in respect of stability against disinfectants. That is why we have tested the activities of three different alcohol-based hand rubs against the two suggested test viruses, and in addition against four other enveloped viruses that represent some of the most relevant or recently-emerging enveloped viruses in human medicine.

\section{Methods \\ Test preparations}

The following alcohol-based hand rubs were tested: Preparation $\mathrm{A}$, based on isopropanol $(45 \%, \mathrm{w} / \mathrm{w}), \mathrm{n}$-propanol $(30 \%, \mathrm{w} / \mathrm{w})$ and mecetronium etilsulfate $(0.2 \%, \mathrm{w} / \mathrm{w})$; preparation $B$, based on ethanol $(80 \%, w / w)$; and preparation $\mathrm{C}$, based on ethanol $(95 \%, \mathrm{w} / \mathrm{w})$. All hand rubs were manufactured by Bode Chemie GmbH \& Co. KG, Hamburg, Germany.

\section{Test viruses}

Virus suspensions that allowed a reduction of at least 4 $\log _{10}$-steps to be measured were used in all experiments. Infectivity assays were performed between 2003 and 2006 according to the test method of the Bundesgesundheitsamt (BGA, Federal Office of Health, now Robert KochInstitute) and the German Association for the Control of Virus Disease (DVV) [15], which uses the same test principle as EN 14476, with the following test viruses:

- Vaccinia virus strain Elstree, passaged and cultured in buffalo green monkey cells (BGM cells) (range of virus titres: 7.6-9.9 $\log _{10} \mathrm{TCID}_{50} / \mathrm{ml}$ )

- Bovine viral diarrhea virus (BVDV) strain NADL, ATCC VR-534, passaged and cultured in KOP-R cells (range of virus titres: $5.5-6.4 \log _{10} \mathrm{TCID}_{50} / \mathrm{ml}$ )

- Herpes simplex virus (HSV) type 1 MacIntyre, ATCC VR539, passaged and cultured in Vero cells (African green monkey kidney, ATCC CCL-81) (range of virus titres: 7.5$\left.8.1 \log _{10} \mathrm{TCID}_{50} / \mathrm{ml}\right)$

- Herpes simplex virus type 2, ATCC VR-540, passaged and cultured in Vero cells (range of virus titres: 7.6-8.5 $\log _{10} \mathrm{TCID}_{50} / \mathrm{ml}$ )

- Human influenza A virus, Panama strain 2007/99 (H3N2), passaged and cultured in Madin-Darby canine kidney epithelial cells (range of virus titres: 5.5-5.9 $\log _{10} \mathrm{TCID}_{50} / \mathrm{ml}$ )

- Avian influenza A virus/duck/Ukraine/1/63 (H3N8), passaged and cultured in Madin-Darby canine kidney epithelial cells (range of virus titres: 6.5-6.9 $\log _{10} \mathrm{TCID}_{50} /$ $\mathrm{ml}$ ). This virus was used as surrogate for $\mathrm{H} 5 \mathrm{~N} 1$ owing to biosafety considerations.

\section{Inactivation assay}

Tests were conducted in accordance with BGA/RKI and DVV guidelines in a waterbath at $20^{\circ} \mathrm{C}$ [15]. Eight parts by 
volume of the disinfectant were mixed with one part by volume of the virus suspension and one part by volume of aqua bidest. This test mixture was investigated at exposure times of 15, 30 and 60 seconds. In tests with different organic loads, one part by volume of the interfering substance was added instead of aqua bidest. The disinfectant was inactivated immediately at the end of the chosen exposure time by serial dilution with ice-cold cell culture medium or by gel filtration with MicroSpin ${ }^{\mathrm{TM}} \mathrm{S}-400 \mathrm{HR}$ columns (Amersham Biosciences Europe GmbH, 79021 Freiburg, Germany), which were used according to the manufacturer's instructions, to reduce the cytotoxicity of the product when BVDV or either of the influenza viruses was tested. Virus controls without columns were run in parallel.

Owing to the addition of virus suspension and organic load, disinfectants could only be evaluated as $80 \%$ solutions.

Virus controls were incorporated after the longest exposure time ( $60 \mathrm{~s})$. One part by volume of virus suspension was mixed with nine parts by volume of aqua bidest. or with one part by volume of organic load and eight parts by volume of aqua bidest.

One experiment was performed for each hand rub, each exposure time, each virus and each type of organic load.

\section{Types of organic load}

Different types of organic load were used (final concentrations):

- No organic load (aqua bidest.)

$\cdot 10 \%$ fetal calf serum

- $0.2 \%$ bovine serum albumin

- $0.03 \%$ bovine serum albumin ("clean conditions" according to EN 14476:2005)

- $0.3 \%$ bovine serum albumin with $0.3 \%$ washed sheep erythrocytes ("dirty conditions" according to EN 14476:2005).

\section{Determination of cytotoxicity}

To determine the cytotoxicity of the disinfectants, two parts by volume of aqua bidest. were mixed with eight parts by volume of the disinfectant, diluted with ice-cold cell culture medium and inoculated into permissive cells. Controls for the different organic loads consisted of one part by volume of aqua bidest, one part by volume of organic load and eight parts by volume of the disinfectant. Any microscopic changes in the cells were recorded when the tests were read for cytopathic effects (CPE). This control allowed cytotoxicity and viral CPE to be clearly differentiated.

\section{Determination of infectivity}

Infectivity was determined in a micro-procedure by endpoint dilution titration. At the end of each exposure time, the test mixture was immediately diluted with ice-cold cell culture medium, and $100 \mu \mathrm{l}$ of each dilution were placed in 8 wells of a sterile polystyrene flat-bottomed 96-well microtitre plate (Nunc A/S, 4000 Roskilde, Denmark) with a preformed cell culture monolayer. The microtitre plates were incubated at $37^{\circ} \mathrm{C}$ with $5 \% \mathrm{CO}_{2}$ for the appropriate incubation time (3-10 days). Cultures were observed for the presence or absence of CPE. The infective dose $\left(\mathrm{TCID}_{50}\right)$ was calculated according to the method of Spearman [16] and Kärber [17]. Titre reduction was calculated as the difference between the virus titres of the water control $(60 \mathrm{~s})$ and the products after the contact times, and is presented as the reduction factor (RF). The following formula was used:

$\mathrm{RF}=\mathrm{a}-\mathrm{b}$

$\mathrm{a}=\log _{10} \mathrm{TCID}_{50} / \mathrm{ml}$ of the control titration

$\mathrm{b}=\log _{10} \mathrm{TCID}_{50} / \mathrm{ml}$ of the test virus titration (after hand rub exposure)

A reduction of infectivity of $\geq 4 \log _{10}$-steps (inactivation $\geq$ $99.99 \%$ ) was regarded as evidence of sufficient virucidal activity against the tested virus according German and European guidelines [15].

\section{Results}

The cytotoxicity of the hand rubs was $2 \log _{10}$-steps in all cell lines. Only hand rub $\mathrm{C}$ was toxic to MDCK cells at 1:1000 dilution.

All three alcohol-based hand rubs reduced the infectivity of vaccinia virus and BVDV by $\geq 4 \log _{10}$-steps within $15 \mathrm{~s}$, irrespective of the type of organic load (Table 1). Similar reduction factors were seen within $15 \mathrm{~s}$ against the other four enveloped viruses (HSV type 1 and 2; human and avian influenza A virus) with or without organic load (Table 1).

\section{Discussion}

Limited data have been published on the spectrum of virucidal activity of alcohol-based hand rubs $[18,19]$. In particular, HBV has been described as an enveloped virus that may be less easy to inactivate $[19,20]$.

By testing three commonly-used alcohol-based hand rubs containing at least $75 \%$ alcohol, we were able to show 


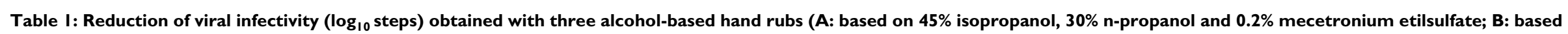
on $80 \%$ ethanol; C: based on $95 \%$ ethanol) against the six different enveloped viruses with different types of organic load.

Hand rub Type of organic load* $\quad$ VVaccinia virus $\quad$ HSV I

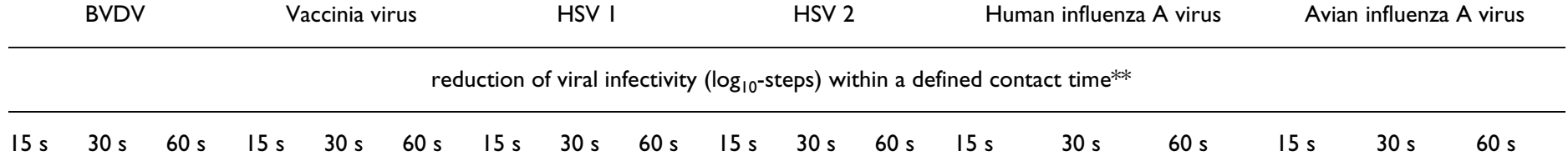

$A$

None

$\geq 4.3 \quad \geq 6.3$

$10 \%$ FCS

$\geq 4.3$

$\geq 5.3$

$\geq 4.0$

s. $15 \mathrm{~s}$

$0.2 \%$ BSA

$\geq 4.8 \quad \geq 5.6$

$\geq 4.3$

$\geq 4.8 \quad \geq 4.3$

$\geq 4.3$

$\geq 4.8 \quad \geq 4.4$

$\geq 5$.

"clean conditions"

$\geq 4.7 \quad \geq 5.7$

$\geq 4.0$

$\geq 5.0$

$$
\geq 4.3
$$

"dirty conditions"

$$
\geq 4.5
$$

$\geq 6.4$

$\geq 4.4$

$\geq 4$.

$\geq 4.4$

$\geq 4.0$

$\geq 5.3$

$\geq 5.0$

$\geq 4$. 1

\begin{tabular}{|c|c|c|c|c|c|c|c|}
\hline \multirow[t]{5}{*}{ B } & None & $\geq 4.3$ & $\geq 5.0$ & $\geq 4.4$ & $\geq 4.4$ & $\geq 4.3$ & $\geq 5.1$ \\
\hline & $10 \%$ FCS & $\geq 4.0$ & $\geq 5.3$ & $\geq 4.4$ & $\geq 4.4$ & $\geq 4.4$ & $\geq 5.3$ \\
\hline & $0.2 \% \mathrm{BSA}$ & $\geq 4.0$ & $\geq 5.3$ & $\geq 4.4$ & $\geq 4.4$ & $\geq 4.3$ & $\geq 5.3$ \\
\hline & "clean conditions" & $\geq 4.0$ & $\geq 5.0$ & $\geq 4.6$ & $\geq 4.5$ & $\geq 4.4$ & $\geq 5.0$ \\
\hline & "dirty conditions" & $\geq 4.2$ & $\geq 5.4$ & $\geq 4.5$ & $\geq 4.6$ & $\geq 4.0$ & $\geq 5.4$ \\
\hline \multirow[t]{5}{*}{ C } & None & $\geq 4.4$ & $\geq 4.8$ & $\geq 4.3$ & $\geq 4.4$ & $\geq 4.3$ & $\geq 5.1$ \\
\hline & $10 \%$ FCS & $\geq 4.5$ & $\geq 4.5$ & $\geq 4.3$ & $\geq 4.4$ & $\geq 4.4$ & $\geq 5.3$ \\
\hline & $0.2 \% \mathrm{BSA}$ & $\geq 4.9$ & $\geq 4.1$ & $\geq 4.0$ & $\geq 4.4$ & $\geq 4.3$ & $\geq 5.3$ \\
\hline & "clean conditions" & $\geq 4.9$ & $\geq 4.5$ & $\geq 4.4$ & $\geq 4.0$ & $\geq 4.4$ & $\geq 5.0$ \\
\hline & "dirty conditions" & $\geq 4.7$ & $\geq 5.5$ & $\geq 4.0$ & $\geq 4.4$ & $\geq 4.0$ & $\geq 5.4$ \\
\hline
\end{tabular}

$\geq 5.4$

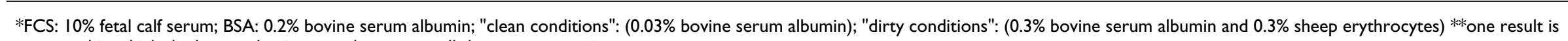
presented in which the $\log _{10}$ reduction was the same at all three exposure times 
that the data obtained with vaccinia virus and BVDV indicated that the preparations are also active against other enveloped viruses relevant to human medicine. According to the declaration of the RKI and DVV the preparations have "limited virucidal activity" and can be considered active against all enveloped viruses relevant to human medicine. "Activity" is the common term in Europe to describe the spectrum of activity in quantitative suspension tests ("in vitro"), whereas "efficacy" is used to describe the effect measured in experiments under practical conditions ("in vivo"). Suspension tests are important for determining the spectrum of activity. Nevertheless, better recommendations can be derived from experiments under practical conditions (phase 2, step 2 tests) such as the ASTM method E-1838-02 [21]. However, some of the above-mentioned viruses cannot be tested on human hands for reasons of biosafety. Furthermore, the type of organic load might strongly influence the virucidal efficacy on hands [22].

All hand rubs were tested at exposure times of 15, 30 and $60 \mathrm{~s}$. The $30 \mathrm{~s}$ exposure time best resembles the practical use of hand rubs in hygienic hand disinfection. All the hand rubs tested have a total alcohol concentration of $75 \%$ or more. It would also have been interesting to study alcohol-based hand rubs with a lower alcohol concentration to verify the data in a more challenging experimental setting. However, hand rubs with $70 \%$ alcohol or less have been shown to have only limited bactericidal activity and should therefore not be used in hospitals $[23,24]$. Thus, it did not seem to be clinically relevant to verify the activity of such hand rubs against enveloped viruses.

We also found that all the types of organic loads tested in these experiments hardly impaired the activities of the hand rubs against the different enveloped viruses. It has previously been shown using feline calicivirus that the type of organic load may significantly influence the mean reduction of viral infectivity in a test under practical conditions [22]. That is why it seemed crucial to confirm activity not only against different viral species but also under various types of organic load. The real bioburden on healthcare workers' hands, however, may consist of blood, pus, serum, sebum, triglycerides, surface active agents and carbohydrates [25]. The greatest reduction of activity has been reported with blood [25]. It has also been found that the bactericidal efficacy of alcohol-based hand rubs is not significantly impaired if hands are contaminated with $1.2 \mathrm{ml}$ blood [26]. On the basis of our data and the results from Larson and Bobo [24], it is unlikely that the presence of blood would significantly impair the activity of alcohol-based hand rubs against enveloped viruses. For clinical practice it is recommended to use alcohol-based hand rubs if hands are not visibly soiled [1]. Whenever hands are visibly dirty or visibly soiled a hand wash should be performed [1]. That is why our results with rather low quantities of organic load support the confidence into the activity of the tested hand rubs against enveloped viruses when the hand rubs are used as recommended on clean hands.

Viral infectivity was reduced to below the limit of detection in all experiments at $15 \mathrm{~s}$ (which is half as long as the current clinical application time for hand rubs) irrespective of the viral species, the type and amount of organic load, and the type of hand rub. It is technically almost impossible to evaluate application times shorter than $15 \mathrm{~s}$ in such a test because the disinfectant activity is terminated by immediate dilution. Moreover, it would have only limited clinical relevance, since a single application of an alcohol-based hand rub usually ensures a contact time of 25-30 s before the alcohol is evaporated [24].

Activity against both test viruses in a quantitative suspension test does of course not include the inactivation of non-enveloped viruses in vitro. Entero-, rota-, adeno- and noroviruses e.g. are in general more resistant than BVDV and vaccinia virus. A virucidal activity (effectiveness against all viruses) of a hand disinfectant is difficult to achieve requiring normally a high concentration of ethanol [3] or some kind of synergistic effect. In many situations in medical settings an activity against enveloped viruses is sufficient for a hand rub [3]. On wards with recurrent viral infections or during outbreaks caused by non-enveloped viruses, a hand disinfectant with virucidal activity is absolutely necessary to interrupt the transmission of viruses by human hands.

\section{Conclusion}

Overall, commonly-used alcohol-based hand rubs with $75 \%$ alcohol or more can be assumed to be active against clinically relevant enveloped viruses if they reduce the infectivities of vaccinia virus and BVDV in the presence of different standard organic loads by $\geq 4 \log _{10}$-steps. It will be important to confirm our results with selected enveloped viruses including surrogate viruses applying test methods using the finger pads or the whole hand of volunteers.

\section{Competing interests}

The first author is paid employee of Bode Chemie $\mathrm{GmbH}$ \& Co. KG, Hamburg, Germany, which funded the study.

\section{Authors' contributions}

GK, JS and HR participated in the study design and coordination. JS carried out the experiments. GK drafted the manuscript. All authors read and approved the final manuscript. 


\section{Acknowledgements}

The study was funded by Bode Chemie GmbH \& Co. KG, Hamburg, Germany. The sponsor participated in the study design, analysis and interpretation of data, writing of the manuscript and the decision to submit the manuscript for publication.

\section{References}

I. Boyce JM, Pittet D: Guideline for hand hygiene in health-care settings. Recommendations of the healthcare infection control practices advisory committee and the HICPAC/SHEA/ APIC/IDSA hand hygiene task force. MMWR - Morbidity \& Mortality Weekly Report 2002, 5 I : I-45.

2. Rotter ML: Arguments for the alcoholic hand disinfection. Journal of Hospital Infection 200I, 48:S4-S8.

3. Kampf G, Kramer A: Epidemiologic background of hand hygiene and evaluation of the most important agents for scrubs and rubs. Clinical Microbiology Reviews 2004, I 7:863-893.

4. Kampf G: The six golden rules to improve compliance in hand hygiene. Journal of Hospital Infection 2004, 56:S3-S5.

5. Rotter ML: European norms in hand hygiene. Journal of Hospital Infection 2004, 56:S6-S9.

6. prEN 12054: Chemical disinfectants and antiseptics. Quantitative suspension test for the evaluation of bactericidal activity of products for hygienic and surgical handrub and handwash used in human medicine. Test method and requirements (phase 2, step I). 1997.

7. Kampf G, Hollingsworth A: Validity of the four European test strains of prEN I 2054 for the determination of comprehensive bactericidal activity of an alcohol-based hand rub. Journal of Hospital Infection 2003, 55:226-23I.

8. DIN EN 1275: Chemische Desinfektionsmittel und Antiseptika. Allgemeine fungizide Wirkung. Prüfverfahren und Anforderungen (Phase I). 1997.

9. EN 14476:2005: Chemical disinfectants and antiseptics. Virucidal quantitative suspension test for chemical disinfectants and antiseptics used in human medicine. Test method and requirements (phase 2, step I). 2005.

10. Anonymous: Leitlinie der Deutschen Vereinigung zur Bekämpfung der Viruskrankheiten e.V. und des Robert Koch-Institutes zur Prüfung von chemischen Desinfektionsmitteln auf Wirksamkeit gegen Viren in der Humanmedizin. Bundesgesundheitsblatt 2005, 48: | 420- | 426.

II. Anonym: Prüfung und Deklaration der Wirksamkeit von Desinfektionsmitteln gegen Viren. Stellungnahme des Arbeitskreises Viruzidie* beim Robert Koch-Institut (RKI) sowie des Fachausschusses Virusdesinfektion der Deutschen Gesellschaft zur Bekämpfung der Viruskrankheiten (DVV) und der Desinfektionsmittelkommission der Deutschen Gesellschaft für Hygiene und Mikrobiologie (DGHM). Bundesgesundheitsblatt 2004, 47:62-66.

12. Sattar SA, Tetro J, Springthorpe VS, Giulivi A: Preventing the spread of hepatitis $B$ and $C$ viruses: where are germicides relevant? American Journal of Infection Control 2001, 29:187-197.

13. Zitzmann N, Mehta AS, Carrouee S, Butters TD, Platt FM, McCauley J, Blumberg BS, Dwek RA, Block TM: Imino sugars inhibit the formation and secretion of bovine viral diarrhea virus, a pestivirus model of hepatitis $C$ virus: implications for the development of broad spectrum anti-hepatitis virus agents. Proceedings of the National Academy of Sciences of the USA 1999, 96: I 1878-1 | 882.

14. Buckwold VE, Beer BE, Donis RO: Bovine viral diarrhea virus as a surrogate model of hepatitis $C$ virus for the evaluation of antiviral agents. Antiviral Research 2003, 60:I-I5.

15. Anonym: Richtlinie des Bundesgesundheitsamtes und der Deutschen Vereinigung zur Bekämpfung der Viruskrankheiten e.V. zur Prüfung von chemischen Desinfektionsmitteln auf Wirksamkeit gegen Viren. Bundesgesundheitsblatt 1982, 25:397-398.

16. Spearman C: The method of 'right or wrong cases' (constant stimuli) without Gauss's formulae. British Journal of Psychology 1908, 2:227-242

17. Kärber G: Beitrag zur kollektiven Behandlung pharmakologischer Reihenversuche. Archiv für experimentelle Pathologie und Pharmakologie 1931, 162:480-487.
18. Kampf G, Rudolf M, Labadie JC, Barrett SP: Spectrum of antimicrobial activity and user acceptability of the hand disinfectant agent Sterillium Gel. Journal of Hospital Infection 2002, 52: $|4|-\mid 47$.

19. Payan C, Pivert A, Kampf G, Ramon C, Cottin J, Lemarie C: Assessment of new chemical disinfectants for HBV virucidal activity in a cell culture model. Journal of Hospital Infection 2004, 56:S58-S63.

20. Payan C, Cottin J, Lemarie C, Ramon C: Inactivation of hepatitis $B$ virus in plasma by hospital in-use chemical disinfectants assessed by a modified HepG2 cell culture. Journal of Hospital Infection 200I, 47:282-287.

21. ASTM E 1838 - 02: Standard test method for determining the virus-eliminating effectiveness of liquid hygienic handwash and handrub agents using the fingerpads of adult volunteers. 2002.

22. Kampf G, Grotheer D, Steinmann J: Efficacy of three ethanolbased hand rubs against feline calicivirus, a surrogate for norovirus. Journal of Hospital Infection 2005, 60: I44-I49.

23. Kramer A, Rudolph P, Kampf G, Pittet D: Limited efficacy of alcohol-based hand gels. The Lancet 2002, 359:|489-|490.

24. Kampf G, Kramer A: Efficacy of hand hygiene agents at short application times. American Journal of Infection Control 2005, 33:429-43I.

25. Ulrich JA: Antimicrobial efficacy in the presence of organic matter. In Skin microbiology Edited by: Maibach $\mathrm{HI}$ and Aly R. New York, Springer; 1981:149-157.

26. Larson E, Bobo L: Effective hand degerming in the presence of blood. The Journal of Emergency Medicine 1992, I0:7-II.

\section{Pre-publication history}

The pre-publication history for this paper can be accessed here:

http://www.biomedcentral.com/1471-2334/7/5/prepub
Publish with Bio Med Central and every scientist can read your work free of charge

"BioMed Central will be the most significant development for disseminating the results of biomedical research in our lifetime. "

Sir Paul Nurse, Cancer Research UK

Your research papers will be:

- available free of charge to the entire biomedical community

- peer reviewed and published immediately upon acceptance

- cited in PubMed and archived on PubMed Central

- yours - you keep the copyright

Submit your manuscript here:

http://www.biomedcentral.com/info/publishing_adv.asp
BioMedcentral 